\title{
Local Study of the Causes of Labor Migration in the City of Krasnoyarsk (October-November 2015)
}

\author{
Natalia P. Koptseva*, \\ Galina S. Soshina and Daria S. Shestopalova \\ Siberian Federal University \\ 79 Svobodny, Krasnoyarsk, 660041, Russia
}

Received 02.06.2015, received in revised form 19.11.2015, accepted 27.01.2016

The results of the local study of the causes and attendant circumstances of labor migration in the city of Krasnoyarsk are presented in the article. The study was conducted in October and November 2015. The main method of research is questionnaires. The concepts of "acculturation", "inculturation" and "acculturation shock", introduced in the conception of the well-known Canadian and American sociologist J. Berry were theoretical foundation of the study. Based on J. Berry's theory and empirical research, conclusions about the peculiarities of the migration process in the city of Krasnoyarsk have been made.

Keywords: ethnic mobility, labor migration, the city of Krasnoyarsk, survey, post-Soviet space.

The article is written with the financial support of Krasnoyarsk Regional Fund of Support Scientific and Scientific and Technical Activities (Project "Creating a corpus of texts for children in their native languages (Evenks, Nenets, Nganasan, Dolgan) as a way to preserve the unique cultural heritage of Indigenous Peoples of Krasnoyarsk Krai”).

DOI: 10.17516/1997-1370-2016-9-4-824-836.

Research area: culture studies.

\section{Introduction}

For problematization it is necessary to introduce and differentiate the concepts of inculturation and acculturation.

Acculturation is the process of interrelation of cultures (the exchange of cultural features), full or partial perception of the culture of one nation by another nation. At that, the original cultural models of one or both groups could be altered, but the groups are still distinct. It is necessary to distinguish between acculturation and assimilation, in which one nation completely loses its language and culture in contact with another, more dominant one. At that, undoubtedly, acculturation can be the first step on the way to complete assimilation.

Inculturation is a process of inclusion of an individual into culture, the adoption of specific habits, norms and stereotypes of behavior. In a narrow sense, inculturation in contemporary

(c) Siberian Federal University. All rights reserved

* Corresponding author E-mail address: decanka@mail.ru 
culture is understood as child's perception of cultural norms and values. In a broader sense, this process is not limited to the period of childhood, but also includes the adoption of cultural stereotypes by an adult. In the latter case, the term is applied to immigrants who adapt to a new cultural environment. Complex aspects of adaptation, related to the entry into another cultural environment, are described through it. The term "inculturation" was introduced by the American cultural anthropologist M.J. Herskovits in 1948.

The purpose of the study is to identify local peculiarities of migrants' inculturation into Russian society and to show that inculturation is an anti-conflict social strategy that is most effective for social integration. To achieve the purpose, a survey among migrant workers of the city of Krasnoyarsk was conducted, whose task was to identify the status of migrants in the local cultural environment.

\section{The Course of Study and Its Empirical Foundation}

In the course of the study the set purpose to conduct a survey among migrant workers in
Krasnoyarsk, which task was to identify the migrants' status in the local cultural environment, has been reached.

The survey was conducted among people, who work in the territory of "Kitai-Gorod" and "KrasTETS" market in the course of direct conversation in October-November 2015. In total 120 people were interviewed.

The survey questions and distribution of answers by the respondents' ethnicity are given below.

\section{Question 1. How do you evaluate}

the local population's attitude

towards you? (Fig. 1)

It can be seen that a small number of the respondents from Armenia and Azerbaijan feel hostile attitude. Meanwhile, labor migrants from Tajikistan have differed in opinions. They equally feel tolerant and indifferent attitude. In general, according to the survey results, migrants have different opinions on the local population's attitude towards them, but nobody mentioned evident hostile attitude (Fig. 2).

This perception has been divided according to the age criteria. It has been revealed that most

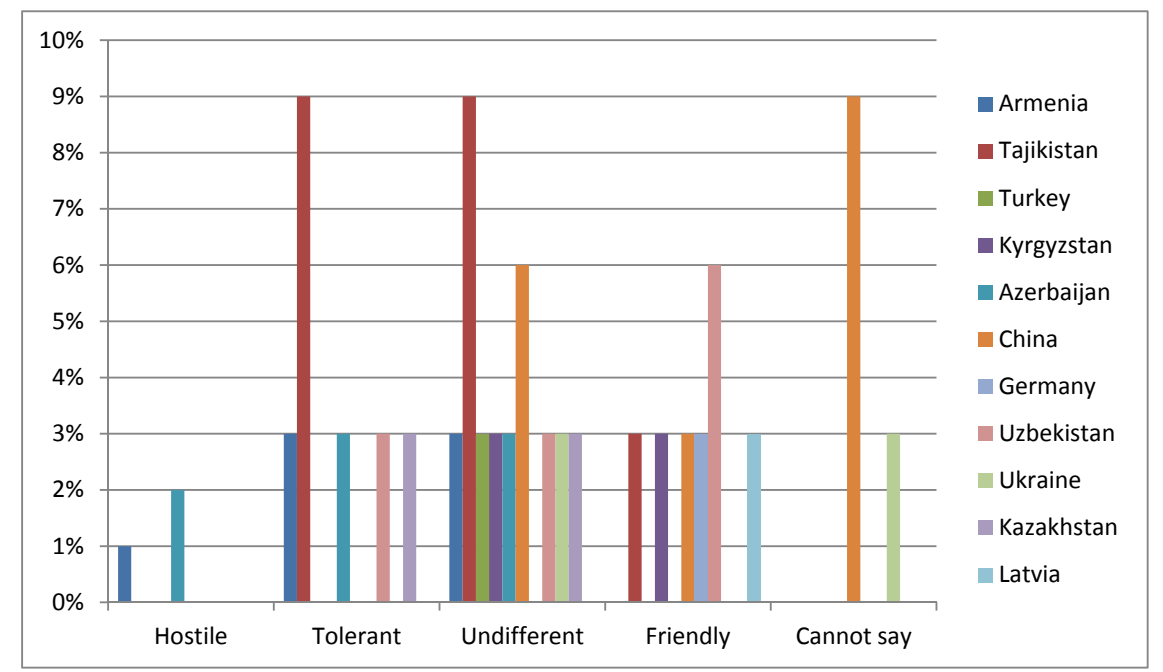

Fig. 1 


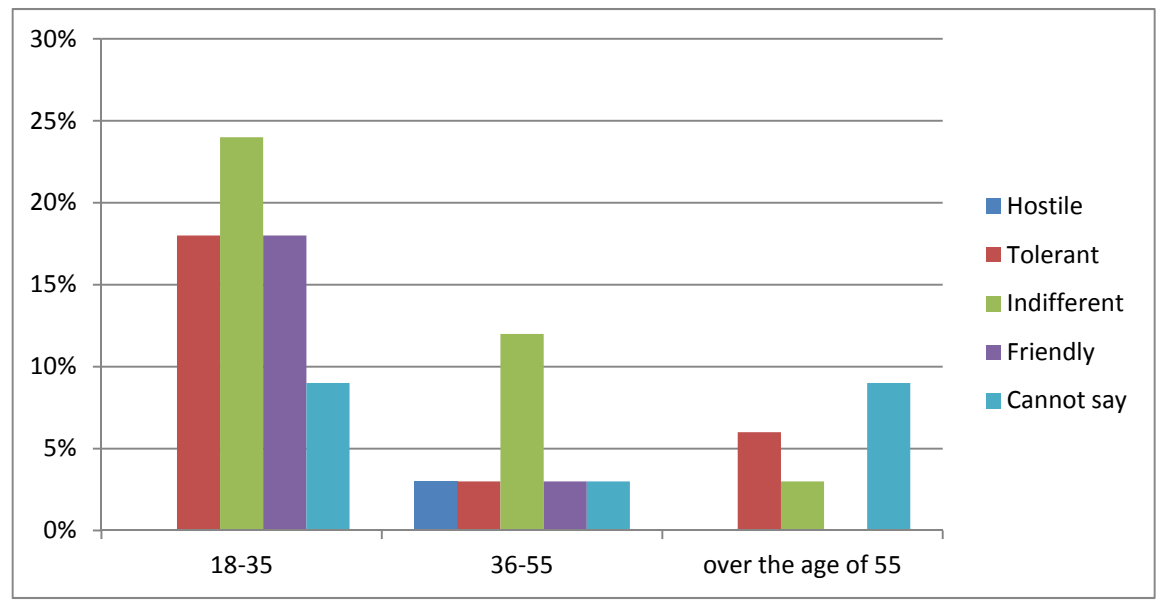

Fig. 2

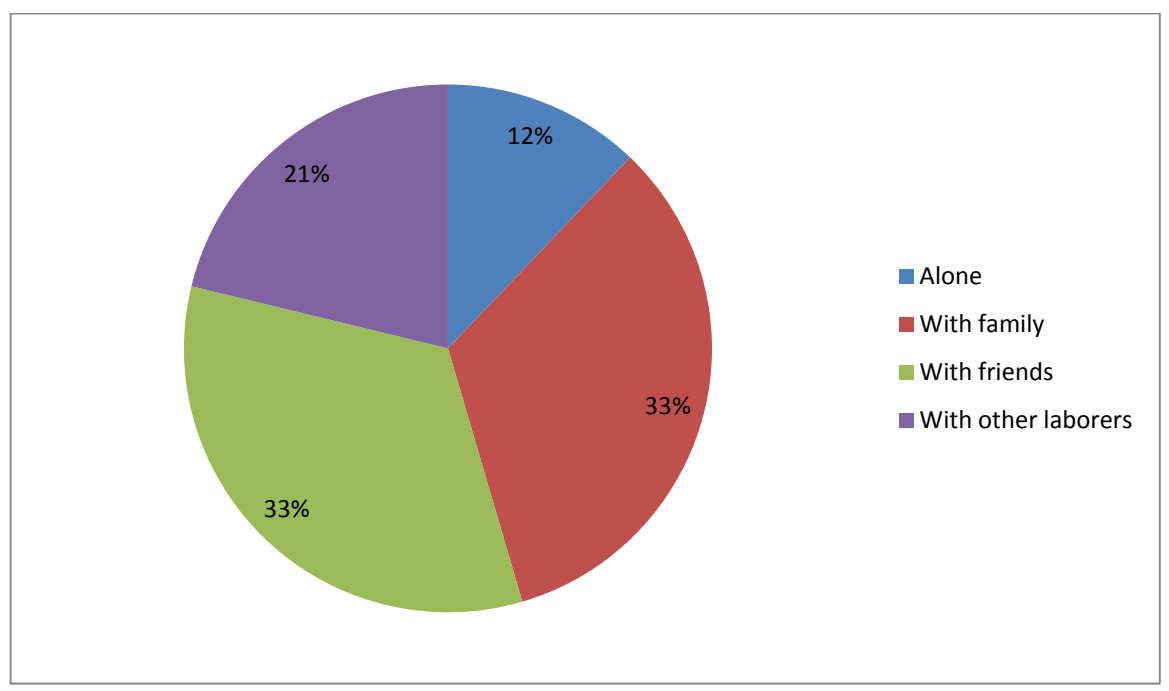

Fig. 3

often all the age groups experience indifferent attitude.

\section{Question 2. You came to Russia}

(Fig. 3)

From the chart it is clear that an equal number of migrants arrive with family and friends. People seldom come to work alone. It might be connected with the fact that is it easier to undergo difficulties in a foreign country with friends and other laborers; they take their families with them as well, not to separate with the family and take care of them.

Question 3. Can you feel any

of your rights oppression by the citizens/ government of the Russian Federation?

(Fig. 4)

In this category there is a tendency that young migrants feel oppression of their rights less than other age groups. On the other hand, the older generation regularly mentions unfair 


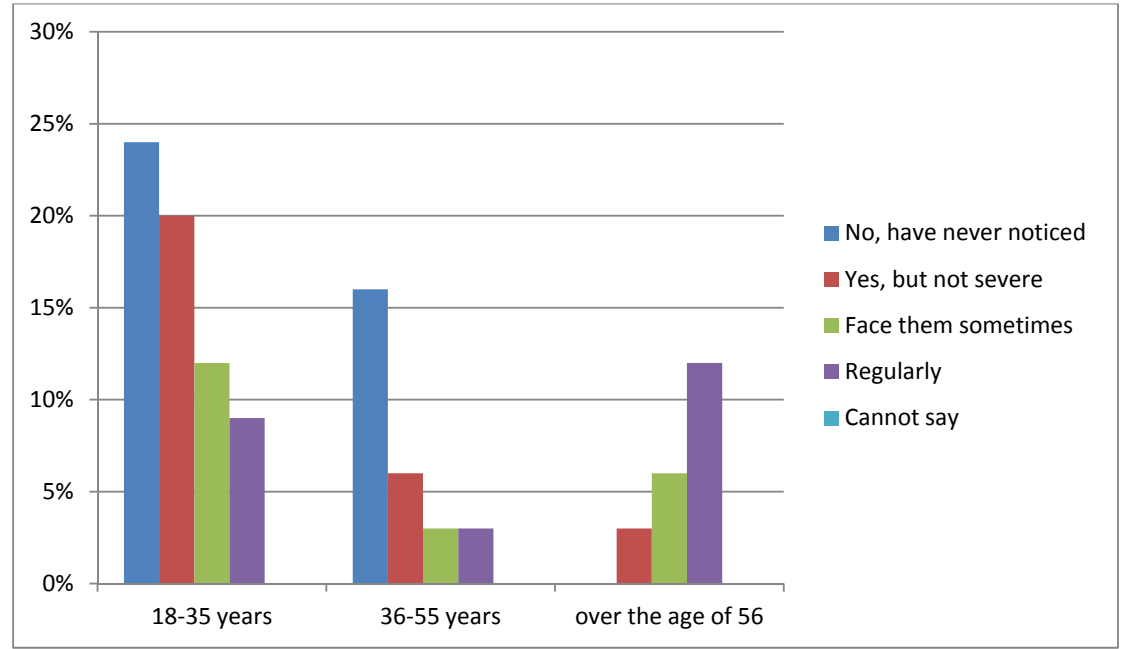

Fig. 4

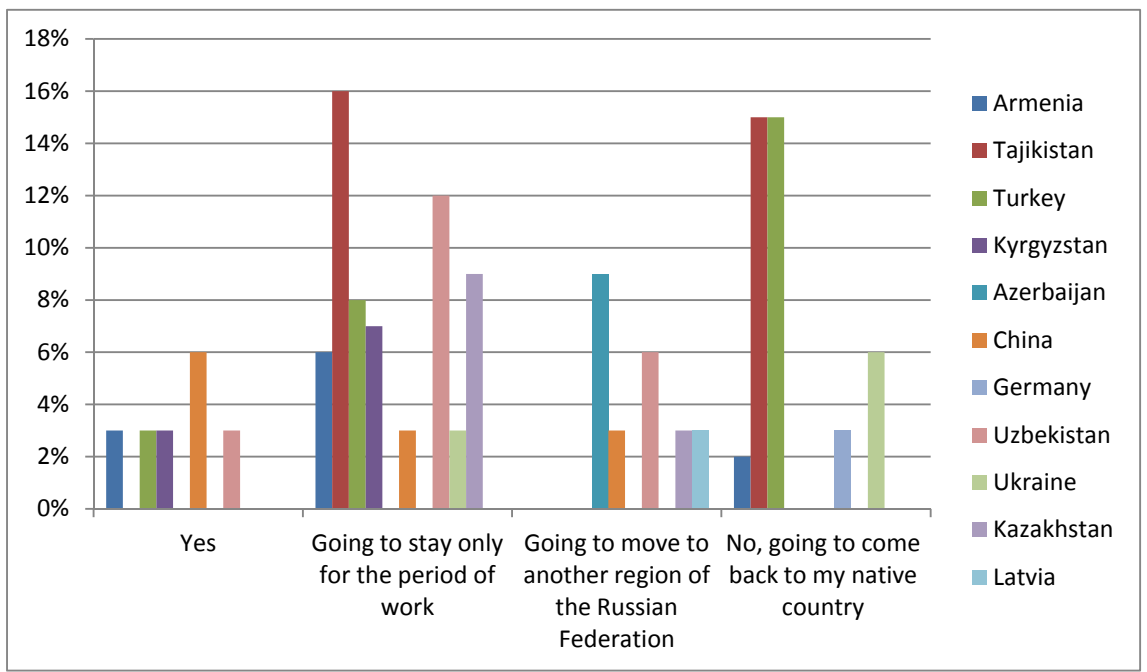

Fig. 5

attitude. This may indicate of the fact that young people adapt in society easier and do not feel any oppressions.

Question 4. Are you going to stay in the Krasnoyarsk Territory in the future? (Fig. 5)

In the diagram on the national criterion it can be seen that citizens of Tajikistan and Turkey are not going to stay in our country for a long period, probably because of the purpose of their visit. They come to the Krasnoyarsk Territory to work for quite a short period of time.

\section{Question 5. You are going to work (Fig. 6)}

Citizens of Ukraine, Kazakhstan and Latvia tend to work in the team with Russian people. On the other hand, migrants from Tajikistan, Kyrgyzstan, China and Uzbekistan are equally going to work in a team of people of their nation. 


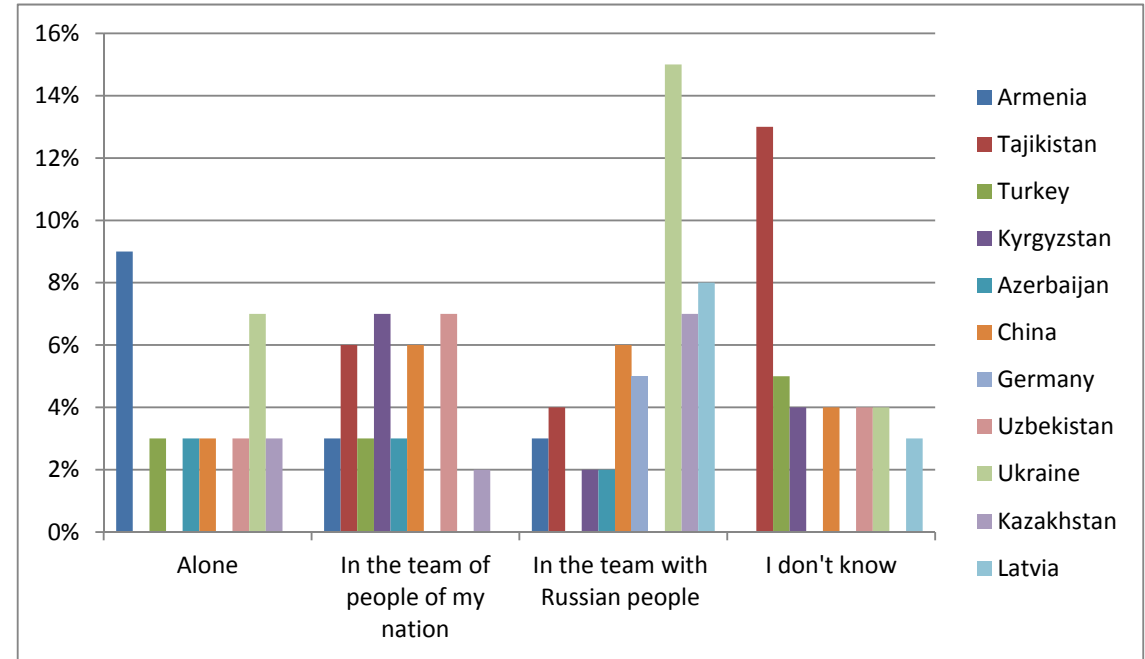

Fig. 6

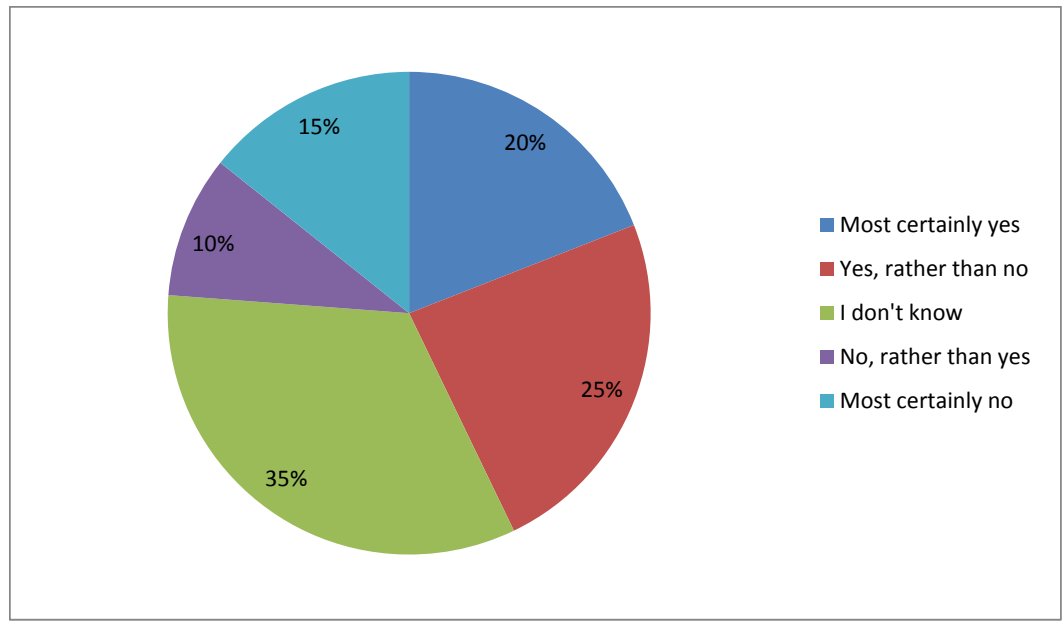

Fig. 7

Possibly, it is connected with the fact that people whose mentality is close to the Russian, tend to work in one team with them.

\section{Question 6. Are you going to continue} studying the Russian language and adopting Russian culture? (Fig. 7)

For a lot of respondents it was difficult to answer, but nearly half of the respondents gave a positive answer. This is certainly a positive tendency, as the process of inculturation is impossible without mastering the necessary knowledge, norms, values and patterns of behavior that allow an individual to function as a full member of society.

\section{Question 7. What was your reason to come to work to the Russian Federation? (Fig. 8)}

Most respondents mentioned higher salary, free job market and bigger choice of activities, and it is the reason why they come to the 


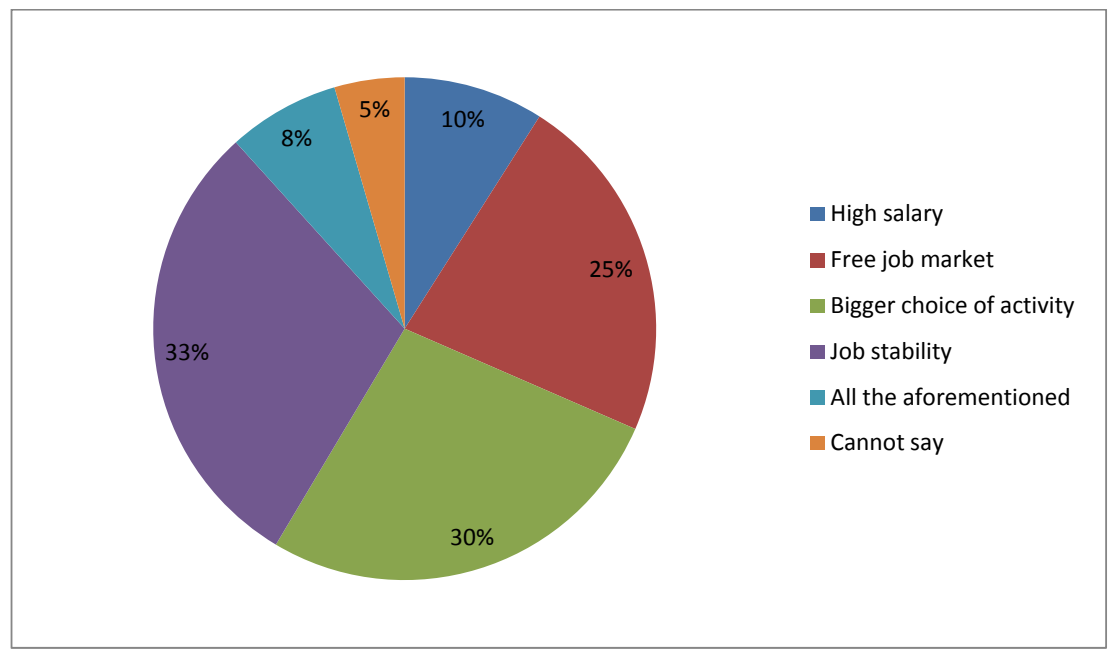

Fig. 8

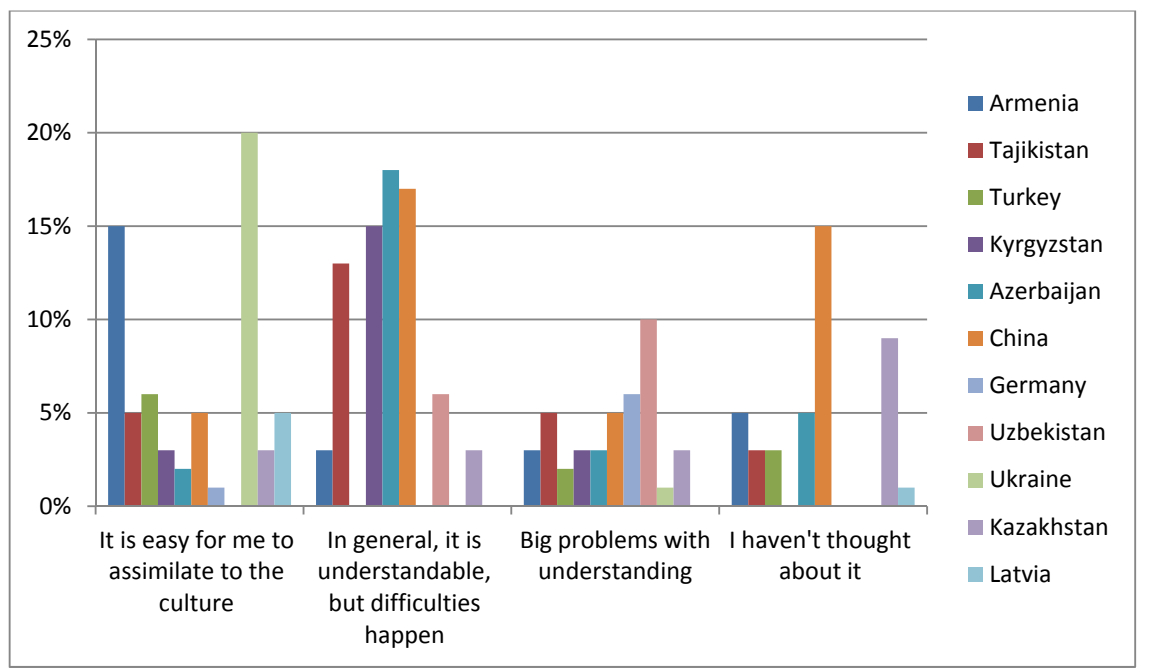

Fig. 9

Krasnoyarsk Territory to work. From this, it is possible to conclude that in comparison to their native countries the Territory is more prosperous in these issues.

\section{Question 8. How well}

do you understand Russian culture?

(Fig. 9)

The perception of Russian culture is easy for the citizens of Ukraine and Armenians. Federation.
Such results are explained by the fact that Ukraine and Armenia have the same religion as Russia. Also, the majority of respondents, in general, understand Russian culture; only migrants from Uzbekistan face the problems. This can be explained by the fact that the citizens of this state have their own traditional views that in some aspects do not coincide with the cultural space of the Russian 
Question 9. Was it easy

for you to adapt

in our country? (Fig. 10)

This graph follows the conclusions of the question about rights oppression. Again, there is a tendency that a category of young migrant workers more easily adapt in society; the process of acculturation for them goes easy. Young people find it easier to cope with the changes in life and the change of environment.
Question 10. Do you know where

to report when your rights are violated?

(Fig. 11)

This chart shows that the majority of labor migrants are fully aware of the services they should report to if their rights are violated. It should be noted that we have a good positive outcome of the awareness of migrants in our region. Although, we should certainly try to enlarge the percentage of the informed migrants.

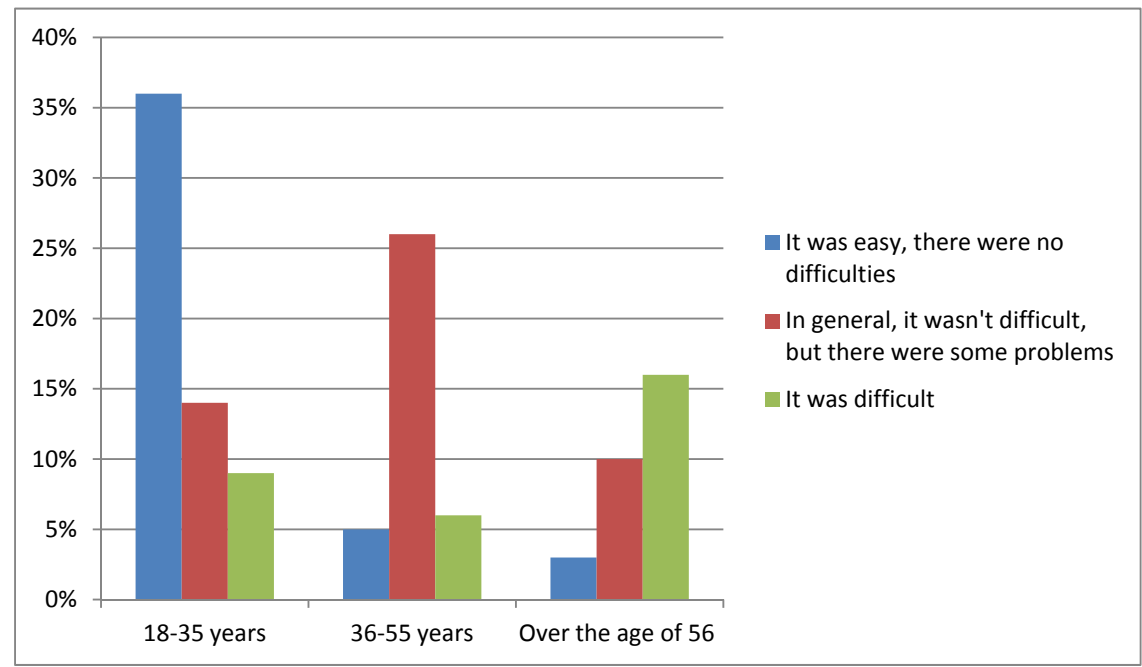

Fig. 10

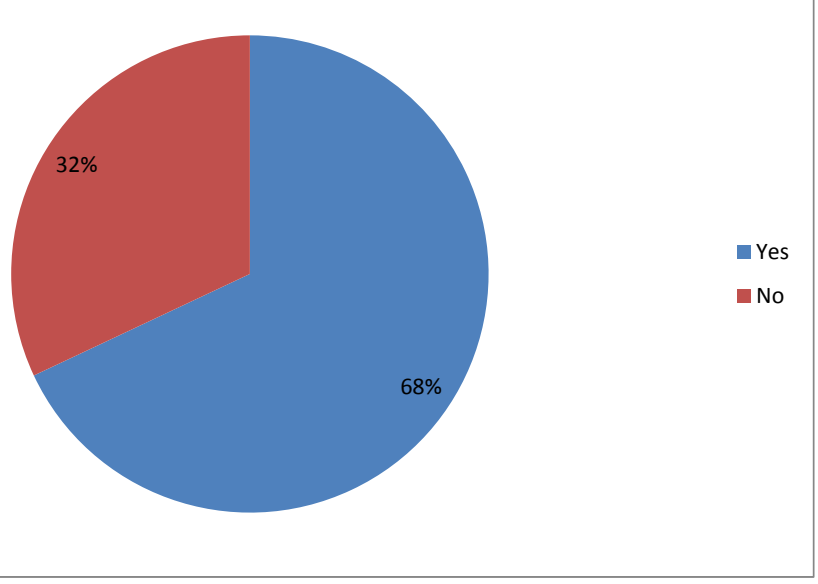

Fig. 11 


\section{Resume}

Migrants have different opinions about the local population's attitude towards them, but nobody mentioned evident hostile attitude. They rarely come to work alone. It is much easier for a small group to socialize in a different cultural environment, as acculturation stress is less intense.

Young people easier adapt in the society, while the older generation regularly mentions unfair attitude.

People, close to the Russian mentality, tend to work with them in one team. People with the similar cultural environment adopt the culture easier. The majority of the respondents note some difficulties adopting Russian culture, but, in general, they do not consider this process difficult.

The majority of labor migrants are perfectly aware of the services to which they should report, if their rights are violated. Almost half of the respondents are going to continue studying the Russian language and adopting Russian culture. This is, certainly, a positive tendency, as the process of inculturation is impossible without mastering the necessary knowledge, norms, values and patterns of behavior that allow an individual to function as a full member of society.

\section{References}

Agrawal, A., Cockburn, I., McHale, J. (2006). Gone But Not Forgotten: Knowledge Flows, Labor Mobility, and Enduring Social Relationships, In Journal of Economic Geography, 6 (5), 571-591.

Arce, E., Segura, D. A. (2016). Stratification in the Labor Market, In the Wiley Blackwell Encyclopedia of Race, Ethnicity, and Nationalism.

Artuc, E., Lederman, D., Porto, G. (2015). A Mapping of Labor Mobility Costs in the Developing World, In Journal of International Economics, 95 (1), 28-41.

Baglioni, A.S., Boitani, A., Bordignon, M. (2015). Labor Mobility and Fiscal Policy in a Currency Union.

Bartel, A.P. (1982). Wages, Nonwage Job Characteristics, and Labor Mobility, In Industrial \& Labor Relations Review, 35 (4), 578-589.

Burton, J.F., Parker, J.E. (1969). Interindustry Variations in Voluntary Labor Mobility, In Industrial and Labor Relations Review, 199-216.

Gallaway, L.E., Gilbert, R.F., Smith, P.E. (1967). The Economics of Labor Mobility: An Empirical Analysis, In Economic Inquiry, 5 (3), 211-223.

Greenwood, M.J. (1969). An Analysis of the Determinants of Geographic Labor Mobility in the United States, In The Review of Economics and Statistics, 189-194.

Greenwood, M.J. (2016). Perspectives on Migration Theory-Economics, In International Handbook of Migration and Population Distribution, Springer, Netherlands, 31-40.

Ilbeykina, M.I., Kolesnik, M.A., Libakova, N.M., Sitnikova, A.A. (2015). Global and Local Trends In Development of Siberian City of Krasnoyarsk, In Mediterranean Journal of Social Sciences, 6 (3), 241-248.

Kang, B. (2016). What Best Transfers Knowledge? Capital, Goods, and Labor in East Asia, In Economics Letters.

Koptseva, N.P., Kirko, V.I. (2014). Specificity of Ethnogeny Indigenous Peoples by Central Siberia in the Transition From the Traditional Type of Society to Modern Society, In Life Sci J , 11 (7), 409413. 
Koptseva, N.P., Kirko, V.I. (2014). Modeling of the Basic Processes and Traditional Way of Life of Indigenous Peoples of Krasnoyarsk Region (Eastern Siberia), In Life Sci J, 11(10), 489-494.

Lee, D., Wolpin, K. I. (2006). Intersectoral Labor Mobility and the Growth of the Service Sector, In Econometrica, 74 (1), 1-46.

Levy, M.B., Wadycki, W.J. (1973). The Influence of Family and Friends on Geographic Labor Mobility: An International Comparison, In The Review of Economics and Statistics, 198-203.

Mincer, J., Jovanovic, B. (1979). Labor Mobility and Wages.

Mitchell, O.S. (1982). Fringe Benefits and Labor Mobility, In Journal of Human Resources, 286298.

Oettl, A., Agrawal, A. (2008). International Labor Mobility and Knowledge Flow Externalities, In Journal of International Business Studies, 39 (8), 1242-1260.

Pritchett, L. (2006). Let Their People Come: Breaking the Gridlock on Global Labor Mobility. Washington, DC, Center for Global Development.

Reynolds, L.G. (1951). The Structure of Labor Markets: Wages and Labor Mobility in Theory and Practice. Harper.

Tabuchi, T., Thisse, J. F. (2002). Taste Heterogeneity, Labor Mobility and Economic Geography, In Journal of Development Economics, 69 (1), 155-177.

Zamarayeva, Y.S., Kistova, A.V., Pimenova, N.N., Seredkina, N.N. (2015). Taymyr Reindeer Herding As a Branch of The Economy And a Fundamental Social Identification Practice For Indigenous Peoples of The Siberian Arctic, In Mediterranean Journal of Social Sciences, 6 (3), 225-232. DOI: 10.5901/mjss.2015.v6n3s5p225

Zhuang, D.Y., Huang, X.J. (2015). Empirical Research on the Influences From Seed Subsidies and Labor Mobility on Food Yield in China, In Advance Journal of Food Science and Technology, 9 (5), 346-350.

Avdeeva Y.N., Libakova, N.M.(2015). Mezhdunarodnye praktiki sotsiokul'turnogo proektirovaniia po otnosheniiu k korennym malochislennym narodam Severa, Sibiri i Dal'nego Vostoka [International Practices of Sociocultural Planning in Relation To Indigenous Small-Numbered Peoples of the North, Siberia and the East Asia], In Sociodynamics, 10, 10-38. DOI: 10.7256/2409-7144.2015.10.16430. Available at: http://e-notabene.ru/pr/article_16430.html

Aleksandrov, D.A., Ivaniushina, V.A., Kazartseva, E.V. (2015). Etnicheskii sostav shkol i migratsionnyi status shkol'nokov v Rossii [Ethnic Composition of Schools and Migration Status of School Students in Russia], In Voprosy obrazovaniia [Educational Studies], (2),173-196.

Berezhnova M.I., Pimenova, N.N. (2015). Migratsiia kak sredstvo razvitiia territorii: istoricheskii primer Kolymskogo kraia [Migration as Means of the Territory Development: Historical Example of Kolyma Region], In Sovremennye Problemy Nauki i Obrazovaniia [Modern Problems of Science and Education], 1, 1888.

Zamaraeva, Y.S. (2014). Osobennosti etnicheskoi migratsii v sotsial'no-psikhologicheskom vospriiatii (na materiale analiza rezul'tatov eksperimenta po metodike "Seriinye tematicheskie assotsiatsii") [Peculiarities of Ethnic Migration in Social and Psychological Perception (Through the Material of Analysis of the Experiment According to the Methodology "Serial Thematic Associations")], In NB: Problemy politiki i obshchestva [Issues of Society and Politics], 9, 63- 
82. DOI: 10.7256/2306-0158.2014.9.13407, Available at: http://e-notabene.ru/pr/article_13407. html

Zamaraeva, Y.S. (2014). Teoriia, istoriographia i metodologiia issledovaniia phenomena migratsii v kontekste sovremennoi philosophii kul'tury [Theory, Historiography and Methodology of Studying the Phenomenon of Migration in the Context of the Modern Philosophy of Culture], In Sovremennye Problemy Nauki i Obrazovaniia [Modern Problems of Science and Education], 4, 600.

Zaslavskaya, T.I., Ryvkina, R.B. (Eds.) (1974). Metodologicheskie problemy sotsiologicheskogo issledovaniia mobil'nosti trudovykh resursov [Methodological Problems of Sociological Research of Labor Resources Mobility]. Novosibirsk, "Nauka” Publishing House.

Ilbeykina, M.I. (2014). Osobennosti visual'no-antropologicheskikh issledovanii indigennykh narodov [Peculiarities of Visual-Anthropological Studies of Indigenous Peoples], In Sovremennye Problemy Nauki i Obrazovaniia [Modern Problems of Science and Education], (4), 594.

Kabalina, V.I. (1999). Trudovaia mobil'nost': organizatsionnye, institutsional'nye i sotsial'nostructurnye factory [Labor Mobility: Organizational, Institutional and Social and Structural Factors], In Sotsiological Zhurnal [Journal of Sociology], (3-4), 20.

Kistova, A.V. (2015). Vliianie etnicheskikh migratsionnykh protsessov na samoopredelenie korennykh malochislennykh narodov Sibiri (na primere etnicheskoi gruppy "chulymy" Tiukhtetskogo raiona Krasnoiarskogo kraia) [Influence of Ethnic Migration Processes on Self-Determination of Indigenous Small-Numbered Peoples of Siberia (Exemplified by "Chulym" Ethic Group From Tyukhtetsky District of the Krasnoyarsk Territory)]), In Sovremennye Problemy Nauki i Obrazovaniia [Modern Problems of Science and Education], 1, 1887.

Kistova, A.V. (2014). Formirovanie kommunikativnogo (interpretativnogo) etnographicheskogo metoda $\mathrm{v}$ sovremennom sotsial'nom poznanii [Formation of Communicative (Interpretative) Ethnographic Method in the Modern Social Cognition], In NB: Problemy politiki i obshchestva [Issues of Society and Politics], 11, 62-72. DOI: 10.7256/2306-0158.2014.11.1352. Available at: http://enotabene.ru/pr/article_13527.html

Kovalevsky, V.A., Kirko, V.I. (2015). Strategicheskoe upravlenie regional'nym pedagogicheskim universitetom $\mathrm{v}$ usloviiakh global'nykh i local'nykh riskov [Strategic Management of Regional Pedagogical University Under Conditions of Global and Local Risks], In Sovremennoe Obrazovanie [Modern Education], 2, 45-69. DOI: 10.7256/2409-8736.2015.2.14393. Available at: http://e-notabene. ru/pp/article_14393.htm

Kolesnik, M.A. (2014). Sotsiologicheskie issledovaniia voobrazheniia v 30-e - 80-e gg. 20 veka [Sociological Studies of Imagination in the $30 \mathrm{~s}-80 \mathrm{~s}$ of the $20^{\text {th }}$ Century], In NB: Problemy politiki $i$ obshchestva [NB: Issues of Society and Politics], 11, 45-61. DOI: 10.7256/2306-0158.2014.11.1351. Available at: http://e-notabene.ru/pr/article_13517.html

Koptseva, N.P., Kistova, A.V. (2015). Konstruirovanie etnokul'turnoi i obshchenatsional'noi identichnosti kak philosophskaya problema [Designing Ethnocultural and Nation-Wide Identity as a Philosophical Problem], In Philosophia i kul'tura [Philosophy and Culture], 1, 12-19. DOI: 10.7256/1999-2793.2015.1

Koptseva, N.P., Reznikova, K.V. (2013). Metodologicheskie vozmozhnosti antropologicheskoi shkoly "Kul'tura-i-Lichnost" dlia sovremennykh rossiiskikh sotsial'no-kul'tyrnykh issledovanii [MethodologicalOpportunities of Anthropological School "Culture-and-Personality" for Contemporary 
Russian Social and Cultural Studies], In Sovremennye Problemy Nauki i Obrazovaniia [Modern Problems of Science and Education], 4, 388.

Koptseva, N.P., Sertakova, E.A. (2015). K voprosu o metodologicheskoi strategii sovremennoi urbanisticheskoi antropologii [To the Question of Methodological Strategy of the Modern Urban Anthropology], In Gumanitarnye i sotsial'nye nauki [Humanities and Social Sciences], 1, 103-120.

Koptseva, N.P., Seredkina, N.N. (2013). Konstruirovanie positivnoi etnicheskoi identichnosti v polikul'turnoi systeme [Developing Positive Ethnic Identity in Polycultural System]. Krasnoyarsk, Siberian Federal University Publishing House.

Libakova, N.M., Sertakova, E.A., Kolesnik, M.A., Sitnikova, A.A., Ilbeykina, M.I. (2016). Sovremennye strategii sotsional'nogo positsionirovaniia sibirskikh regionov [Modern Strategies of Social Positioning of Siberian Regions], In Sociodynamics, 1, 162-189. DOI: 10.7256/24097144.2016.1.17420. Available at: http://e-notabene.ru/pr/article_17420.html

Lurie S.V. (2016). Opyt poligamnykh semei u sovremennykh rossiiskikh musul'man: narrativnyi analiz [The Experience of Polygamous Families Among Modern Russian Muslims: Narrative Analysis], In Sociodynamics, 1, 92-136. DOI: 10.7256/2409-7144.2016.1.17461. Available at: http://e-notabene.ru/ pr/article_17461.html.10695

Liuev, A. Kh. (2015). Vneshniaia trudovaia migratsiia i konkurentsiia na rossiiskom rynke truda [External Labor Migration and Competition in the Russian Labor Market], In The Bulletin of the Adyghe State University: Regional Studies: Philosophy, History, Sociology Legal Studies, Political Studies, Culturology, 1 (156), 122-127.

Maltseva, I.O. (2009). Trudovaia mobil'nost' i stabil'nost': naskol'ko vysoka otdacha ot spetsifichnogo chelovecheskogo kapitala v Rosii? [Labor Mobility and Stability: How High is the Return on Specific Human Capital in Russia?], In Economic Journal of the Higher School of Economics, 13 (2), 243-278.

Maltseva, I.O., Roshchin, S.Y. (2006). Gendernaia segregatsiia i trudovaia mobil'nost' na rossiiskom rynke truda [Gender Segregation and Mobility on the Russian Labor Market]. Moscow: Higher School of Economics Publishing House.

Nemirovsky, V.G. Nemirovskaya, A.V. (2012). Dinamika sotsiokul'turnykh protsessov v Krasnoiarskom krae (na materialakh sotciologicheskikh issledovanii v regione v 2010-2012 gg.) [Dynamics of Sociocultural Processes in the Krasnoyarsk Territory (Through the Materials of Sociological Studies in the Region in 2010-2012)]. Krasnoyarsk, Siberian Federal University Publishing House.

Nemirovsky, V.G. Nemirovskaya, A.V. (2011). Sotsial'naia struktura i sotsial'nyi kapital naseleniia Krasnoiarskogo kraia [Social Structure and Social Capital of the Krasnoyarsk Territory Population]. Krasnoyarsk, Siberian Federal University Publishing House.

Novikov, A.V. (2015). Vozmozhnosti RF i EAES v regulirovanii trudovoi migratsii [The Possibilities of the RF and the EEU in Labor Migration Regulation], In Science Time, 5 (17), 303 306.

Nonoe budushchee Sibiri: ozhidaniia, vyzovy, resheniia [New Future of Siberia: Expectations, Challenges, Decisions] (2013). Edited by: O.A. Karlova, N.P. Koptseva, Y.N. Moskvich. Krasnoyarsk, Siberian Federal University Publishing House and Krasnoyarsk State Pedagogical University n. a. V.P. Astafiev Publishing House. 
Okladnikova, E.A. (2015). Trudovaia migratsia $v$ narrativakh zhitelei Sankt-Peterburga: etnophobii, konflikty, tekhnologii tolerantnosti [Labor Migration in the Narrations of Saint-Petersburg Dwellers: Ethnophobias, Conflicts, Tolerance Technologies]. Moscow-Berlin, Directmedia Publishing House.

Pimenova, N.N. (2015). Korennye malochislennye narody v sovremennoi situatsii: ob'em i soderzhanie poniatiia [Indigenous Small-Numbered Peoples in the Modern Situation: Volume and Content of the Concept], In Sociodynamics. 1, 112-134. DOI: 10.7256/2409-7144.2015.1.14249. Available at: http://e-notabene.ru/pr/article_14249.html

Reznikova, K.V. (2014). Immigratsionnaia politika zarubezhnykh stran: poisk priemlimykh modelei dlia Rossii [Immigration Policy of the Foreign Countries: Search for the Acceptable for Russia Models], In Sovremennye problemy nauki i obrazovaniia [Modern Problems of Science and Education], 2, 650.

Reznikova, K.V. (2014). K voprosu ob utochnenii poniatii "etnos" i "etnichnost"” [To the Question of Specification of the Concepts of "Ethnos" and "Ethnicity"], In Sociodynamics, 12, 90-102. DOI: 10.7256/2409-7144.2014.12.13913. Available at: http://e-notabene.ru/pr/article_13913.html

Reznikova, K.V. (2015). Etnichnost' kak kategoriia sotsial'nogo poznaniia [Ethnicity as a Category of Social Cognition], In Sociodynamics, 1, 101-111. Available at: 10.7256/2409-7144.2015.1.14228. URL: http://e-notabene.ru/pr/article_14228.html

Reznikova, K.V., Pimenova, N.N., Kistova, A.V., Seredkina, N.N., Zamaraeva, Y.S. (2016). Upravlenie brendingom sibirskoi territorii v svete "novogo regionalizma" [Managing the Branding of Siberian Territory in the Light of "New Regionalism"], In Sociodynamics, 1, 137-161. DOI: 10.7256/2409-7144.2016.1.17395. Available at: http://e-notabene.ru/pr/article_17395.html

Roshchin, S.Y., Razumova, T.O. (2000). Ekonomika truda [Labor Economics]. M., INFRA-M.

Seredkina, N.N. (2014). Etnicheskaia kartina mira v kontekste sovremennykh sotsial'nykh issledovanii [Ethnic Worldview in the Context of Modern Social Studies], In NB: Problemy politiki $i$ obshchestva [Issues of Society and Politics], 10, 26-59. DOI: 10.7256/2306-0158.2014.10.1344. Available at: http://e-notabene.ru/pr/article_13441.html

Sertakova, E.A. (2014). Visualizatsiia obraza goroda i oblika gorozhan v chasovne Paraskevy Piatnitsy v Krasnoyarske [Visualization of the City Image and Image of the City Dweller in the Chapel of Paraskeva Pyatnitsa in Krasnoyarsk], In Urbanistics, (2), 50-64. DOI: 10.7256/2310-8673.2014.2.13271. Available at: http://e-notabene.ru/urb/article_13271.html

Sertakova, E.A., Zamaraeva, Y.S., Sitnikova, A.A. (2015). Sotsiologicheskoe issledovanie kul'turnykh potrebnostei zhitelei goroda Krasnoyarska [Sociological Study of Cultural Needs of the Dwellers of Krasnoyarsk ], In Urbanistics. 3:.16-42. DOI: 10.7256/2310-8673.2015.3.16495. Available at: http://e-notabene.ru/urb/article_16495.html

Sitnikova,A.A.(2015). Demographiia imigratsiia vposelkakh korennykhmalochislennykhnarodov Krasnoiarskogo kraia (poselki Pasechnoe, Essei, Surinda, Farkovo, Nosok, Karaul) [Demography and Migration in the Settlements of Indigenous Small-Numbered Peoples of the Krasnoyarsk Territory (Settlements Pasechnoe, Essey, Surinda, Farkovo, Nosok, Karaul)], In Sovremennye Problemy Nauki i Obrazovaniia [Modern Problems of Science and Education], 1, 1883.

Sitnikova, A.A. (2014). Sovremennye praktiki forsait-issledovanii budushchego sotsial'noantropologicheskikh sistem, $\mathrm{v}$ tom chisle etnokul'turnykh grupp severnykh regionov Rossiiskoi 
Federatsii [Modern Practices of Foresight Study of the Future of Social-Anthropological Systems, Including Ethnocultural Groups of Northern Regions of the Russian Federation], In NB: Problemy politiki i obshchestva [Issues of Society and Politics], 9, 44-62. DOI: 10.7256/2306-0158.2014.9.13405. Available at: http://e-notabene.ru/pr/article_13405.html.

Smirnova, T.B. (2015). Etnicheskie migratsii v Sibiri po dannym statistiki i neformal'nym nabliudeniiam [Ethnic Migrations in Siberia According to Statistical Data and Informal Observations], In Bulletin of Omsk State University, Historical Studies, 1 (5).

\title{
Локальное исследование причин трудовой миграции в городе Красноярске (октябрь-ноябрь 2015 г.)
}

\author{
Н.П. Копцева, \\ Г.С. Сошина, Д.С. Шестопалова \\ Сибирский федеральный университет \\ Россия, 660041, Красноярск, пр. Свободный, 79.
}

\begin{abstract}
В статье излагаются результать локального исследования причин и сопутствуюших обстоятельств трудовой миграции в г. Красноярске. Исследование было проведено в октябре и ноябре 2015 года. Основной метод исследования - анкетирование. В качестве теоретической базы исследования выступили концепты «аккультурация», «инкультурация», «аккультурационный шок», разработанные в концепции известного канадского и американского соииолога Дю. Берри. На основании теории Дж. Берри и эмпирического исследования сделаны выводы о специфике миграционных прочессов в г. Красноярске.
\end{abstract}

Ключевые слова: этническая мобильность, трудовая миграция, г. Красноярск, анкетирование, постсоветское пространство.

Статья написана в рамках исследования, финансируемого Красноярским краевым фондом поддержки научной и научно-технической деятельности (проект "Создание корпусов текстов для детей на их родном языке (эвенкийском, ненеиком, нганасанском и долганском) как способ сохранения уникального культурного наследия коренных народов Красноярского края»).

Научная специальность: 24.00.00 - культурология. 